\title{
LA APROBACIÓN DE LIBROS EN LA LITERATURA NOVOHISPANA DE LOS SIGLOS XVII Y XVIII: LA CENSURA COMO EJERCICIO INTELECTUAL
}

\author{
THE AUTHORIZATION OF BOOKS IN NEW SPAIN \\ IN THE 17TH AND 18TH CENTURIES: CENSORSHIP \\ AS AN INTELLECTUAL EXERCISE
}

\author{
Andrea Mariel Pérez González \\ Universidad Nacional Autónoma de México \\ andreap013@gmail.com \\ orcid: 0000-0002-0488-4101
}

\begin{abstract}
Resumen: La aprobación de libros, un paratexto legal que originalmente servía para otorgar la licencia de impresión, se consolidó en los siglos XVII y xviII en la Nueva España como el espacio idóneo para la aparición del germen de la crítica literaria. Estos paratextos, codificados a partir de ciertos componentes retóricos y elementos constituyentes, son testimonio de un tipo de ejercicio intelectual que caracteriza a este período del Barroco novohispano, un ejercicio en el que convive la censura con la actitud precrítica. Mediante el análisis de un amplio corpus de libros impresos en los siglos XVII y XVIII del virreinato, se propone un acercamiento al paradigma del ejercicio crítico como práctica intelectual, en la que la censura tenía un papel importante.
\end{abstract}

Palabras clave: paratexto; aprobación; censura; crítica literaria; Nueva España.

Aвstract: Official authorization granting a license for books to be printed became a permanent practice in New Spain in the 17th and 18th centuries, providing an ideal context in which literary criticism could emerge. These paratexts, couched in specific rhetorical and literary terms, serve as testimony to a type of intellectual exercise that characterized this colonial baroque period in Mexican cultural life, when censorship coexisted with the first timid attempts at literary criticism. By analyzing a large corpus of books printed in the 17th and 18th centuries, we aim to approach this critical practice, presenting it as both an intellectual exercise and an endeavor in which censorship played an important role.

Keywords: paratext; printing permission; censorship; literary criticism; New Spain.

Recepción: 4 de abril de 2019; aceptación: 13 de febrero de 2020.

D.R. ( ) 2021. Nueva Revista de Filología Hispánica Licencia Creative Commons Attribution-NonCommercial (CC BY-NC) 4.0 International 


\section{INTRODUCCIÓN}

El libro impreso en la Nueva España es testimonio de los distintos mecanismos responsables, tanto de su propia existencia material, cuanto de las leyes -en su mayoría, tácitas- que regulaban los procesos de escritura de los poetas, pensadores y religiosos que conformaban la llamada "Ciudad letrada" (Rama 1998, p. 32). Con la llegada de la imprenta a la Nueva España a mediados del siglo XVI, se apresuró también la legislación sobre la impresión y circulación del pensamiento escrito en el territorio conquistado, a fin de poner el taller de Juan Pablos -y el de sus sucesores- al servicio del proyecto ideologizador de la Corona.

El resultado de ello fue la incorporación, en los preliminares, de una serie de documentos burocráticos que atestiguaban la autorización de las instituciones civiles y eclesiásticas para enviar el libro a las prensas. Estos documentos, que al formar parte del libro se convierten en paratextos -en cuanto que adquieren nuevas funciones relacionales a partir del contacto con el texto central- se volvieron un requisito de impresión a partir de que se promulgara la Pragmática de 1558 en España. En el caso de la Nueva España, no obstante, el control sobre el pensamiento escrito adquiere matices particulares, ya que el paratexto burocrático dedicado a la censura -la aprobación o censura previa- se volvió uno de los instrumentos de institucionalización literaria más determinantes de la cultura impresa novohispana.

La aprobación o censura -también llamada "sentir" o "parecer" en la Nueva España-es uno de los documentos legales que conforman el espacio paratextual del libro, como lo son también el privilegio, la tasa, la fe de erratas y la licencia ${ }^{1}$. A diferencia de éstos, el carácter legal de la aprobación responde no sólo a los requerimientos de la autoridad civil, sino también de la eclesiástica, pues, a partir del Concilio de Trento, se dispuso que el clero ordinario debía evaluar previamente cualquier obra de tema sagrado, así como también se debían someter a evaluación del superior de la orden los libros de autores religiosos. Había, por lo tanto, dos tipos de aprobaciones según la autoridad que las otorgaba: las civiles, que se debían a organismos dependien-

1 Un primer acercamiento al tema de la aprobación de libros se puede encontrar en Pérez González 2018. 
tes de la Corona, aunque "el que fueran civiles no quiere decir que [los censores] no pudieran ser religiosos" (Garone 2014, p. 86) ${ }^{2}$, y las eclesiásticas, que dependían del ordinario y del superior de las órdenes religiosas. A pesar de que la primera legislación sobre la censura previa en el proceso de impresión de libros se debe al Concilio de Trento, no fue sino hasta la Pragmática de 1558 que se formalizó la obligación de incluir en las páginas preliminares del libro la aprobación civil -y, dado el caso, también la eclesiástica-, lo que dificultaba, aunque no impedía del todo, la posibilidad de imprimir libros que no contaran con la aprobación y la licencia correspondientes.

Si bien la necesidad de control en materia de impresión se debió, inicialmente, a la amenaza de la Reforma protestante, a medida que se fue ensanchando el estado burocrático -y se empezaron a promulgar leyes que regularan la estampación y venta de libros-, la preocupación que subyacía a la necesidad de control en la España peninsular y sus colonias se renovó. Como apunta Jacques Lafaye (2002), ya desde la Pragmática de 1554 -decretada por el emperador Carlos V- lo que se reprochaba en el proceso de censura previa no era tanto la herejía, cuanto "la futilidad y la inutilidad, [lo cual era] una forma de decir que el coste del libro era elevado y no se debía malgastar dinero en publicar desvaríos de la fantasía que no pasarían de mero entretenimiento" (p. 48).

A la par de la legislación libresca promulgada en la Península, fue necesario reforzar las restricciones en materia de impresión en la Nueva España, por lo que se llevó a cabo el Primer Concilio Provincial de México (1555), en el que, a raíz de que se hubieran introducido algunos textos sospechosos, se declara prohibido "imprimir o publicar libro sin ser visto y examinado por el Arzobispo o Diocesano” (Reyes Gómez 2000, p. 177). En dicho Concilio, se insistió en el "peligro que representaban la

${ }^{2}$ Es importante mencionar que un análisis detallado de los extensos títulos de estos paratextos deja ver la difícil tarea de diferenciar su adscripción institucional, puesto que la gran mayoría de los censores que los firma ostenta algún puesto religioso, ya sea actual o pasado, lo cual deja ver que incluso las censuras civiles se encomiendan casi en su totalidad a censores religiosos. Respecto de los extensos títulos en las aprobaciones, señala CANCino Cabello que "es una forma de accumulatio que «apabulla» al lector u oyente (no deja lugar a cuestionamientos), y refuerza la conclusión por medio de un argumento que se presenta como si fuera de autoridad" (2017, p. 415). 
impresión y difusión de libros «nocivos»" (Ramos Soriano 2011, p. 74) y se estableció como castigo la pena de excomunión y una multa de cincuenta pesos de minas, o cien, que dependía de si la transgresión se llevaba a cabo en el momento de impresión o de venta.

Desde la llegada de Juan Pablos a territorio americano, se estableció en su contrato la necesidad de contar con la licencia del Obispo de México, que se muestra en los colofones de sus libros. Pero, a partir de la Pragmática de 1558, cuando se hizo obligatoria la impresión de la aprobación y la licencia en las hojas preliminares del libro, la tarea de otorgar licencia se trasladó al virrey y al arzobispo. Tres décadas más tarde, en el Tercer Conclilio Provincial de México, se ratificó que "no se imprimiera obra alguna sin licencia previa del ordinario, ni siquiera las concernientes a la religión traducidas en lenguas indígenas" (Reyes Gómez 2000, p. 207). Adicionalmente, a causa de la polémica suscitada por la publicación de obras de temática indiana, como la de Ginés de Sepúlveda, Iustis belli causis (1550), y la de Francisco López de Gómara, Primera y segunda parte de la Historia de las Indias y Conquista de México (1553), se determinó que todo libro de dicha materia debía ser previamente censurado por el Consejo de Indias, a lo que se debe el hecho de que "el tema americano [tuviera] poca repercusión en la literatura española en el Siglo de Oro, frente a [otros] temas" (p. 184).

En lo que respecta a la función de la censura previa o aprobación, la tarea original del censor consistía en ratificar que el contenido del libro no atentara contra la moral cristiana ni las buenas costumbres. Según atestigua Fernando Bouza (2012) en el panorama español, el proceso iniciaba con la presentación de un memorial de petición de licencia ante el organismo responsable de la censura, donde el dignatario mandaba los originales que eran susceptibles de aprobación al censor que él mismo había seleccionado. El censor recibía el original "signadas sus hojas por un escribano de cámara” (p. 112) y, después de una cuidadosa lectura, aprobaba el texto y escribía la censura o aprobación. Este original, una vez aprobado, se llevaba a la imprenta, y ambos, original e impreso, volvían al Consejo, donde se cotejaban para la expedición de la fe de erratas y la tasa. El autor debía obtener todas las aprobaciones solicitadas antes de llevar el original a la imprenta, algo que derivaba en la extenuante acumulación de documentos legales, como atestigua la declaración de Antonio de Rojas respecto de su libro 
Vida del espiritu para saber tener oración y unión con Dios, publicado en 1629: "Doy gracias a Dios... que el libro de Vida del espiritu está aprobado por un obispo, por cuatro calificadores de la Suprema y nueve aprobaciones de las más graves que ha tenido libro" (Bègue 2009, p. 95).

La aprobación era, por lo tanto, "el informe positivo que tanto el poder civil como eclesiástico otorgaban certificando que la obra en cuestión no contenía nada en contra de la fe ni en contra de las buenas costumbres" (p. 93); y, si bien inicialmente se trataba de un mero trámite para obtener la licencia de impresión, a partir de que se hizo obligatoria su incorporación en las hojas preliminares del libro ${ }^{3}$, el lector se vio progresivamente expuesto al material textual burocrático que no sólo difundía los juicios morales del censor, sino también los literarios. Según señala José Simón Díaz (2000), la redacción de las primeras aprobaciones impresas en España era rutinaria y se limitaba a repetir fórmulas ("He visto por mandado de V.A.", "De orden del Sr." o "Por comisión de..."); y sin descuidar su principal propósito, con una breve alusión a la ortodoxia de la obra que se aprobaba, se liberaba el manuscrito para su publicación, pues "al censor se le preguntaba si la obra contenía algo contra la Fe y Buenas costumbres y con responder que no, había cumplido" (p. 156).

No obstante, cuando este documento pasó a formar parte de los umbrales del texto, sus lectores dejaron de ser sólo el censor y el autor de la obra. Debido a que ahora la aprobación estaba expuesta a los ojos de numerosos lectores, a partir de la segunda mitad del siglo XVI, su estilo comenzó a volverse cada vez más variable y, contrario a lo que cabría esperar -la repetición mecánica de una frase aprobatoria-, se empieza a convertir en un espacio textual más amplio y ambiguo ${ }^{4}$. A lo largo del siglo XVII, la aprobación fue ganando espacio en las pági-

3 Simón Díaz (2000) menciona que aun cuando es la Pragmática de 1558 la que hace obligatoria la impresión de los permisos legales en las páginas preliminares del texto, algunos ya lo hacían siguiendo los dictados del Concilio de Trento, como sucede con Gabriel de Toro, quien en 1548 declara en su Tesoro de Misericordia: "Por quanto en este Concillo Tridentino, se determinó e ordenó, que al principio de los libros que se imprimiesen se pusiese la licencia, examen y aprobación de los prelados ordinarios, por tanto hize imprimir aquí la licencia y aprobación deste libro" (p. 156).

${ }^{4}$ La formulilla de la aprobación, repetida hasta el cansancio en las primeras décadas del siglo Xvi, no escapa a la sátira de los escritores áureos, ya que, como recuerda Simón Díaz (p. 160), cuando en La Dorotea se habla de 
nas preliminares, a la vez que comenzó a adquirir las características de un texto apologético que refleja tanto los intereses del marco institucional que lo promueve, cuanto el gusto particular de los censores. Por ello, a fin de no repetir aquella frase trillada, los autores de la censura empezaron a aprobar otras cuestiones además de la moralidad del contenido, como la prudencia, el estilo o el ingenio del autor.

Hay dos razones principales, a mi entender, por las que se empiezan a incorporar elementos críticos y panegíricos a la aprobación: interesa, en primer lugar, mostrar la utilidad del trabajo del censor, por lo que estos paratextos "debían dejar constancia de los méritos de los autores, la calidad de la obra y los beneficios que redundarían de su publicación" (Bouza 2012, p. 109). En segundo lugar, la llana objetividad de las primeras censuras cede su lugar a la costumbre de algunos censores de dejarse llevar por sus intereses personales, algo que se generaliza a partir de que la firma del censor empieza a aparecer junto a la firma de autores de poesías laudatorias y del mismo autor de la obra literaria ${ }^{5}$. Esta práctica de vanidad intelectual no pasaba desapercibida al lector del Siglo de Oro, para quien no era novedad que el censor quisiera que se viera "su nombre y la cuenta que dél [libro impreso] se hizo en el caso, que faltaría si no saliese el libro aprobado" (p. 139).

Sin embargo, a mi parecer, la razón que subyace a éstas deriva de la mentada ley que en 1558 hizo obligatoria la incorporación de este documento al espacio preliminar del libro. La aprobación, como los paratextos que la acompañan, adquiere en el libro el papel de discurso periférico ${ }^{6}$ que caracteriza

la mujer "más firme, más constante y de más limpia fe y costumbres", uno de los personajes comenta con ironía: "Parece aprouación de libro".

5 Como apunta Pedro Guibovich (2014) al respecto de las aprobaciones en los libros impresos en el virreinato de Perú: "[la censuras que contienen crítica literaria] muchas veces representaban para el censor una inmejorable oportunidad para darse a conocer, es decir, salir del anonimato, haciendo gala de su erudición" (p. 103).

${ }^{6}$ La característica unificadora de todos los paratextos con elementos literarios -burocráticos o no- es la capacidad de emitir un discurso a partir de la obra central. Esta capacidad de crear discursos periféricos es particularmente interesante cuando la centralidad -lo que origina el discurso periférico paratextual-son otros paratextos, como ocurre en la Fama y Obras pósthumas de sor Juana Inés de la Cruz, donde Juan Ignacio de Castorena, el editor y promotor de la obra póstuma, escribe un prólogo en el que comenta no sólo la obra de la poeta mexicana, sino también muchos de los paratextos 
a los demás paratextos literarios -el prólogo, la dedicatoria y las poesías preliminares-; $y$, si bien las funciones de cada paratexto particular son distintas, todos comparten la característica de ser emisores de un discurso a partir del texto central. En suma, la aprobación dejó de responder sólo a las instituciones civiles y religiosas que la encomendaban, y empezó a adaptarse al espacio paratextual que compartía con otros paratextos propiamente literarios, como las poesías preliminares o el prólogo, con lo que modificó los criterios a partir de los cuales se evaluaba la obra para su publicación. Si bien la aprobación no perdió su carácter burocrático, pues siguió siendo uno de los documentos indispensables para la impresión hasta que se decretó la libertad de imprenta, sí adquirió diversas funciones aquiescentes enfocadas en la valoración de la materia, el tema, la pertinencia del estilo utilizado, el uso de autoridades o la trayectoria del autor, aspectos que se atenderán a lo largo de este trabajo.

El corpus analizado incluye, pues, aprobaciones de 52 obras novohispanas de distintos géneros literarios ${ }^{7}$-poesía, novelas, vidas de santos y crónicas- que se imprimieron a lo largo de los siglos XVII y XVIII en México y en España. La selección se hizo tomando en cuenta que el período de florecimiento de este paratexto se dio a lo largo del siglo xviI, ya que los libros de autores novohispanos del siglo Xvi no suelen incluir la aprobación impresa en sus páginas preliminares, o bien, si la incluían, su función era puramente burocrática. Durante el siglo XviII se puede ver, en Nueva España, que la aprobación se vuelve significativamente más extensa que en el siglo anterior, y que cada vez son más numerosas las aprobaciones que constatan la validez de una misma obra literaria.

En las aprobaciones de obras novohispanas de ambos siglos se pueden observar, por lo tanto, extensos panegíricos o discursos críticos en torno al autor y la obra encomendada para su censura. En este sentido, el trabajo del censor se fue adaptando progresivamente para satisfacer los requerimientos de una

que la acompañan, como las poesías preliminares o la famosa aprobación del padre Diego Calleja.

${ }^{7}$ Si bien algunos de estos géneros, como las hagiografías y las crónicas, no entrarían en la categoría de lo literario en nuestros días, vale la pena considerarlos por la fuerte presencia de elementos preceptivos y retóricos con los que se defiende su composición en las aprobaciones, como se verá más adelante. 
empresa intelectual que superaba la mera prohibición de materiales peligrosos. Los censores de libros escribían como hombres de letras, y su trabajo -el discurso crítico y apologético de la obra central- podría considerarse un ejercicio intelectual, ya que, como señala Robert Darnton (2014, p. 29): “censorship was not simply a matter of purging heresies, it was positive -a royal endorsement of the book and an official invitation to read it".

Siguiendo la atinada observación de Darnton, las aprobaciones de libros se constituyen como un trabajo intelectual donde el censor pone a buen uso su juicio crítico para valorar la calidad de la obra y ejercer una suerte de pre-crítica literaria. A la vez, se sirve de ciertos recursos retóricos y lugares comunes que constatan la clara configuración del paratexto como un tratado cuya función crítico-apologética supera el mero propósito de censurar moralmente la obra. Ambas características de la aprobación -el ejercicio crítico para valorar la calidad literaria del texto y el uso de tópicos y recursos estilísticos para embellecer el paratexto- sugieren que los censores se acercaban a la escritura de la aprobación como los hombres de letras lo hacían a otros géneros textuales como el tratado o el panegírico.

\section{EL GERMEN DE LA CRÍTICA EN LAS APROBACIONES DE LIBROS}

La primera asociación entre la aprobación y la crítica literaria en el mundo hispánico se debe a estudiosos del panorama literario español, como José Simón Díaz (2000), Víctor Infantes (2000) y Pedro Ruiz Pérez (2000). Sin embargo, el último es quien analiza con mayor profundidad este fenómeno paratextual y afirma que la crítica literaria tiene cuatro componentes esenciales: principio de autonomía, capacidad de desarrollar un sentido de la mediación entre obra y lector, destinatario del texto crítico y conciencia de la heterogeneidad del público lector. Todos ellos derivan del primero: la posibilidad que ofrece la crítica de emitir un discurso autónomo y ponderado a partir de la obra literaria (Ruiz Pérez 2000, p. 340).

Los antecedentes de la crítica literaria se deben buscar en el siglo Xvi cuando surgen determinados "cambios culturales y epistemológicos... que no pueden desvincularse de unas transformaciones directamente relacionadas con el despliegue de la imprenta y los modos de lectura característicos de ella” (p. 341); 
este período es el que algunos estudiosos hacen coincidir con los albores de la modernidad. No pretendo con esto resumir un fenómeno cultural tan complejo bajo un marbete que puede resultar en exceso simplista; por el contrario, considero más conveniente dilucidar los factores que dieron lugar al surgimiento de la crítica a partir de la ruptura con los modelos clásicos en siglo XVI. En este sentido, señala Ruiz Pérez:

La adscripción del texto a los límites del discurso clásico, con su sentido de utilidad y decoro, su principio de verdad y su consiguiente sometimiento a unas reglas concebidas como eternas, dificulta, si no imposibilita completamente, el ejercicio pleno de la crítica, ya que el texto se impone con un sentido único que no puede ser cuestionado por el receptor, y su gusto, por tanto, no puede ser orientado por quien, desde la posición de lector privilegiado, juega un papel de mediador $(i d$.$) .$

Con la ruptura de los modelos clásicos ocurre un progresivo "desplazamiento del principio de autoridad por el de libertad individual" $(i d$.$) , lo que contribuye a la creación del espacio$ idóneo para el surgimiento de la crítica, pues esta libertad individual no sólo atañe a la tarea del escritor, sino que también permite al crítico tener un juicio estético y literario propio. Esta apertura a la pluralidad en la recepción proviene de un conflictivo cambio en la concepción del texto literario: a inicios del siglo XVI, la valoración del texto como una "realidad sagrada e inmutable" (p. 343) producto de la valoración del modelo bíblico y la atención a las autoridades clásicas convive con una nueva conciencia en la que el texto se considera fruto de la actividad creadora humana.

Ya a finales del siglo XviI en la Nueva España, la primera aprobación que aparece en los preliminares de la Vida del apóstol Santiago (1699) de José Lezamis da cuenta de este cambio en la recepción y valoración del texto, pues fray José Sánchez -censor de libros, calificador del Santo Oficio y catedrático de la Universidad de México- celebra en su crítica de la hagiografía la atinada resolución del autor de utilizar un determinado estilo. A diferencia de la mayoría de las aprobaciones de libros hagiográficos o vidas de personajes ilustres, en ésta el censor considera que se debe otorgar licencia por la singularidad del estilo de su autor y no sólo por el tema, que, como se verá más adelante, es un tópico frecuente en estos paratextos: 
A lo que Vmd. me manda le diga con ingenuidad, con ella le respondo que no tiene cosa alguna, a mi parecer, que pueda impedir la impressión. Antes bien, juzgo que es muy digna de que se imprima porque en ella, quien con afecto la leyere, hallará un terso cristal para componer las ocupaciones exteriores en la vida pública y regular sin faltar a ellas lo que pertenece al aprovechamiento proprio y espiritual utilidad. El estilo en que Vmd. escribe es genuino y proprio: sin digresiones que sirven al lector de molestia, da noticia de lo que obró su Ilustrísima. Sin pedir prestadas erudiciones divinas y profanas, podría Vmd. exornar cada párrafo de los en que divide la vida que describe, pero no lo haze porque sabe que el fin de quien escribe la vida de un sujeto no es llenar muchas planas de sagrados textos, lugares de santos padres y dichos de autores profanos: esto conoce usted es bueno para un libro predicable o mýstico, pero enfadosa cosa en el estilo historial, donde la noticia se busca con ansia y se dessea hallar la verdad en ella, que es quien la haze hermosamente estimable ([p. 115]).

Si bien al inicio del fragmento el censor alude a uno de los principios de la poética clásica -el que empareja el delectare con el docere, según decreta Horacio- como uno de los principales logros de la obra, inmediatamente después alude al estilo "genuino" del autor; con ello, el censor reconoce la libertad del escritor y la deliberada elección de su estilo. No obstante, vale la pena retomar la citada observación de que la crítica surge a partir del rompimiento con los modelos clásicos, pues, como se puede observar en este fragmento, lo que el censor considera aciertos son, precisamente, aspectos de la obra en que el escritor sigue con mayor apego los preceptos clásicos. En primer lugar, remite a la utilidad de la obra y la función que ocupa la belleza del estilo en este primer propósito ${ }^{8}$; en segundo, elogia la claridad de la prosa y la frugalidad en el uso de escolios y referencias cultas ${ }^{9}$; y, por último, celebra la coherencia del estilo con el tema histórico que decidió representar, es decir, valo-

${ }^{8}$ Así lo declara Horacio en la Epístola a los Pisones: "Centuriae seniorum agitant expertia frugis, celsi praeterunt austera poemata Ramnes: omne tulit punctum qui miscuit utile dulci, lectorem delectando pariterque monendo" (vv. 341-346; uso la edición de la Colección Loeb, con traducción a cargo de H. Rushton Fairclough).

${ }^{9}$ Dice también HoRacio: "Quidquid praccipies, esto brevis, ut cito dicta percipiant animi dociles teneantque fideles: omne superavacuum pleno de pectore manat" (vv. 335-338). 
ra el decoro en la narración ${ }^{10}$. Sin duda, sería un error pensar que a finales del siglo XviI, en el ocaso del movimiento estético barroco, la poética clásica se había vuelto obsoleta; muy por el contrario, subsistía -particularmente en la Nueva España- un profundo respeto por la normatividad clásica.

La explicación de la pervivencia de la crítica, no obstante sus orígenes anticlasicistas, requiere de una perspectiva histórica: el arte barroco surge de los "escombros de las grandes construcciones culturales" y se caracteriza por una "incontenible voluntad artística" que encuentra en el estilo elaborado del lenguaje una forma de mantenerse a la altura de los acontecimientos del mundo (Snyder 2014, pp. 31-32). El origen de la crítica está profundamente imbricado en esta nueva concepción del arte y la literatura; sin embargo, su ejercicio se mantiene aun después de que los valores estéticos del Barroco pasaran a considerarse excesos y afectaciones del estilo. Además, como explica Snyder, la esencia del Barroco está, por un lado, en esa "incontenible voluntad artística" de la que habla Walter Benjamin, que consiste en retomar y reformular los elementos más importantes de la tradición; y, por otro, en un nuevo ethos respecto de la autoridad, de donde surge la actitud crítica:

efectivamente, es el movimiento de la misma escritura crítica, el formarse y el enunciarse de las ideas en el inagotable desarrollo del discurso estético, así como su inserción estratégica en el tejido cambiante de la obra, lo que expresa el sentido del texto: ése es esencialmente el modo barroco de pensar acerca del arte barroco (p. 30).

La progresiva experimentación creadora y la ruptura con el paradigma de unicidad y de verdad permitió la existencia de un público lector heterogéneo, capaz de ejercer el juicio crítico basándose en su gusto estético individual. El juicio personal del censor José Sánchez al evaluar la Vida del apóstol Santiago se deja ver mediante comentarios literarios que destacan la aplicación de la poética clásica como un logro, pero las numerosas aprobaciones críticas en los libros novohispanos -y en aquellos de escritores novohispanos que se publicaron en España- muestran que el gusto de los censores puede ser tan variado como la

${ }^{10}$ En la Epístola a los Pisones se define el decoro de la siguiente manera: "Versibus exponi tragicis res comica non volt; indignatur item privatis ac prope socco dignis carminibus narrari cena Thyestae" (vv. 89-91). 
temática y estilo de las obras que evalúan. Así, la primera aprobación de los Desagravios de Christo en el triumpho de su cruz contra el judaísmo, de Francisco Corchero Carreño, publicados en 1649, expresa someramente la opinión del censor respecto de este poema heroico, y tanto el juicio personal del crítico como la poética que describe difieren de la aprobación anteriormente citada:

No he hallado en él cosa que contradiga el cathólico sentir de nuestra santa fee, ni a la christiana piedad de las buenas y ajustadas costumbres, antes juzgo que es un desvelo tan industriosamente fabricado, un afán tan lúcidamente discurrido, que tiene bien merecida en plausibles aclamaciones la luz pública que su autor pretende ([p. 5]).

Lo que el censor de este libro -Iván Hidalgo de Barrios, canónigo de la catedral de México- encuentra valioso del poema es su estilo elaborado, "industriosamente fabricado". Este dictamen ofrece una lectura de la obra distinta a la del sentir de fray Rodrigo de Medinilla -dedicado al mismo poema-, que destaca la sobriedad en las referencias, la variedad de la erudición y la musicalidad de los versos:

lo claro del historiar: al paso que reducido a tan breves copias, en lo afeado de inventivas y frases que a nuestro patrio idioma avivan la elegancia (hypérbole no pequeño en estos tiempos). En lo vario de la erudición... en lo dulce del metro, a que la novedad de consonancias añade dulçuras ([p. 9]).

Estas aprobaciones, pareceres o sentires -el de Rodrigo de Medinilla no es una aprobación burocrática, sino un texto crítico-apologético que escribe un amigo del autor ${ }^{11}$-ayudan a

${ }^{11}$ No se me escapa la necesidad de ahondar en las diferencias entre los títulos bajo los que aparece este paratexto en las páginas preliminares del libro: "censura", "aprobación", "sentir" y "parecer". Estos paratextos, cuya función es en apariencia la misma, se han visto siempre como homólogos, a pesar de la gran diferencia que impone el hecho de que dos de ellos -"aprobación" y "censura”- sean inexorablemente burocráticos. En los impresos estudiados para el presente artículo, "aprobación” es el membrete más común, aunque "sentir" y "parecer" se presentan también con mucha frecuencia e incorporan todos los elementos formales (tópicos y características constituyentes, que expondré más adelante) del "género" paratextual que engloba el término "aprobación". Los elementos críticos y teóricos de este paratexto tienen aún más relevancia cuando se constata que su cohesión 
ejemplificar la situación de este ejercicio pre-crítico en las aprobaciones novohispanas, pues, aunque no coincide en términos históricos con la conceptualización de Ruiz Pérez, sí presenta las características fundamentales para su existencia; en concreto, principio de autonomía del texto crítico y su sentido de la mediación entre obra y lector, lo cual se mantiene no obstante la poética que el censor decida defender.

Conocer los orígenes de la crítica puede dar algo más de claridad sobre su funcionamiento en los paratextos novohispanos. Para unos estudiosos, como Viñas Piquer (2002), el comentario filológico del humanismo -heredero de la glosa medieval que comparte algunos intereses con la ecdótica- es donde encontramos por primera vez una actitud "crítica" en la historia de la literatura ${ }^{12}$. Para otros, como Ruiz Pérez (2000), el comentario filológico no es más que un antecedente de la crítica literaria, puesto que su función principal es reforzar la autoridad del texto, a pesar de que la figura del filólogo humanista -a diferencia del copista medieval- sea consciente de los cambios históricos que ha sufrido la obra literaria y reconozca su papel de intérprete, algo que contribuye a formar "una disciplina compartida a lectores que se sumarán a la tarea de la interpretación" (p. 344).

La aparición de la crítica en el mundo hispánico está asociada a la propuesta estética personal del crítico, por encima de la necesidad de canonizar el texto. Si bien aquello se puede encontrar en algunos comentaristas del humanismo, no es sino hasta

formal y el uso de recursos retóricos se mantienen aun cuando el paratexto no tiene una función burocrática, como es el caso del último paratexto citado, el parecer no legal de Rodrigo de Medinilla, que aparece en las páginas preliminares del libro bajo el rótulo de "carta".

12 Considero pertinente distinguir entre la exégesis literaria, presente en la historia de la literatura desde la Antigüedad, y la crítica profesionaliza$\mathrm{da}$, aquella que establece un discurso crítico -producto de un juicio literario personal y ponderado- a partir de la obra y que surge en relación con los nuevos hábitos de consumo de libros en los Siglos de Oro. Por su parte, David Viñas PiQuer (2000) inicia el recorrido de lo que llama "crítica" en el siglo vi a.C. y, a su vez, señala que en la Edad Media "los juicios formales son juicios utilitarios que se apoyan en consideraciones éticas. Así, los aspectos formales, de los que depende sobre todo el placer estético, pasan a ocupar un lugar absolutamente secundario", de manera que lo que hoy entendemos por crítica literaria vino a sustituir una labor filológica -la exégesis o comentario- con la que se reforzaba la autoridad del texto, un pretendido reflejo de la verdad (p. 108). 
el siglo XVII, con la aparición de la "aprobación politextual"13, que el ejercicio crítico se independiza de su primera función canonizadora y se convierte en un discurso autónomo que parte del juicio personal de un lector profesionalizado, el censor que firma estos paratextos aprobatorios. El parecer del doctor Samaniego al Panegýrico augusto castellano (1639), de Juan Rodríguez de León, está plagado de alusiones al juicio personal del lector, algo que sirve de testimonio a la apertura del espacio paratextual para el ejercicio de la pre-crítica:

Mucho tiempo e gastado en leer los escritos referidos y todo se me ha hecho, para passarlos, tan gustoso como corto, por la elegancia del estilo, retórico de palabras y razonado de sentencias. He hallado en ellos un raro ingenio, elección propria, discursos peregrinos, disposición nueva, pensar extraordinario y retórica de singular elocuencia ([p. 15]).

Este panegirista -no podemos llamarlo censor, porque el título de este sentir no legal es "elogio del doctor Samaniego"-, antes de referirse a los aciertos estilísticos de la obra, alude a su propia experiencia como lector, lo que sugiere que su juicio literario parte de la subjetividad. No es coincidencia que el autor de este paratexto se refiera a la originalidad de la obra -"raro ingenio, elección propria..., disposición nueva"-y, a la vez, se ponga a sí mismo como receptor en el centro del paratexto, ya que una de las funciones de la crítica es destacar la propuesta estética de ese primer lector, lo cual se facilita si la obra misma tiene una propuesta estética original, pues, como he mencionado, el origen de la crítica está asociado a la aparición de la estética individual de los escritores y la ruptura con los modelos clásicos, algo de lo que algunas obras representantes del período son testimonio.

\section{LA CONVIVENCIA DE LA ACTITUD PRE-CRÍTICA Y LA CENSURA}

La aprobación en el siglo XviI es, pues, el espacio donde se ejerce una suerte de crítica literaria que atiende a los principios

13 La aprobación politextual es el término con el que IGNACio García Aguilar (2009, p. 100) se refiere al fenómeno, propio del siglo xviI, por el cual se estampan múltiples aprobaciones en los preliminares del libro impreso español, muchas de ellas de carácter crítico y no burocrático. 
de autonomía y conciencia de la heterogeneidad del público lector, aunque pervive en este período el modelo de crítica que responde a "la burda actuación de raíz inquisitorial" (Ruiz Pérez 2000 , p. 354), contraria al ejercicio intelectual en que desempeña un papel primordial la "finura del juicio crítico". De ahí que sea necesario distinguir este nuevo modo de lectura crítica en el marco de la censura previa como institución -es decir, la aprobación de libros-, del papel legitimador del lector dogmático, el "zoilo", que se sirve del comentario filológico para ejercer un tipo de censura, no sólo moral, sino también literaria:

El siglo XVII [se sitúa] en medio de los dos modelos que van a formalizar el ejercicio crítico en prácticas estables y consolidadas: de una parte, la de los libros impresos para el mercado, la ya mencionada censura o aprobación prescrita por la legislación sobre el libro, juicio obligado e institucional encomendado a un cuerpo de letrados, que cobran un salario, es decir, que se decantan hacia una suerte de profesionalización; de otra parte, la de las selectas, semiprivadas e inéditas academias, el preceptivo vejamen, que cierra como una sanción la sesión académica y se aproxima formalmente al modelo de la crítica, si bien en el fondo de su decantación al tópico -fruto de su convencionalidad y su tono jocoso y descomprometido- la convierte, como en el caso de la censura inquisitorial en sus antípodas, en una antítesis de la crítica $(i d$.$) .$

Estos dos modos de ejercer la crítica no resultaban ajenos al lector de la época; tanto es así que algunos de los censores novohispanos, al evaluar la obra, hacen comentarios con que se anticipan a los dictámenes de ambos tipos: el del que parte de preceptos inflexibles y con frecuencia es incapaz de ofrecer un juicio crítico, y el de aquel que, por el contrario, está en la disposición de analizar una obra sopesando sus logros estéticos frente al gusto propio. Un ejemplo es la aprobación de fray Miguel de Aroche a El peregrino septentrional atlante (1737), de Isidro Félix de Espinosa ${ }^{14}$, cuyas primeras líneas recogen las dos

14 Isidro Félix de Espinosa nació en la ciudad de Querétaro en 1679 y murió en 1755 en la misma ciudad. Ingresó al Colegio de la Cruz en 1696 y se ordenó sacerdote en 1703, el mismo año en que empezó su actividad misionera en Texas y Río Grande, al lado de fray Antonio Margil de Jesús, personaje que protagoniza dos de sus obras principales: El peregrino septentrional atlante (1737) y Nuevas empresas del peregrino americano septentrional atlante (1747). Publicó también, entre muchas otras obras, El cherubín custiodio del árbol de la vida (1731). 
posturas contrapuestas: "La vida que se delinea es la del R.P. Fr. Antonio Margil de Jesús, decoroso lustre de los apostólicos missioneros de nuestra América, en la que tendrán los zoilos poco o nada que advertir y los aplicados muchas heroicas virtudes que imitar" ([p.12]).

Lo que esto nos dice es que, paradójicamente, el surgimiento de la lectura crítica coincide con la sistematización del control del pensamiento escrito, que se ejerce ya sea mediante la censura previa - la aprobación, germen de la crítica- o la censura inquisitorial a posteriori, más dada a la condena dogmática. Esta dicotomía entre la crítica vista como ejercicio intelectual y, a la vez, como una forma de censura, se mantendrá en el espacio paratextual de las obras literarias novohispanas hasta finales del siglo XviII.

Uno de los casos más notables de la convivencia de ambos discursos es quizás el de las aprobaciones en las obras impresas de sor Juana Inés de la Cruz, en particular las de los primeros dos volúmenes, la Inundación castálida (1689) y el Segundo volumen (1692). La composición del espacio paratextual de estos dos volúmenes refleja una postura de generalizada confusión de los críticos a quienes se debe el discurso crítico-apologético que sentó las bases para la primera recepción de las obras impresas de la poeta mexicana. Conviven, en el espacio paratextual de ambos volúmenes, acertadas reflexiones poéticas que reflejan la visión crítica del censor o panegirista con juicios un tanto desatinados que pretenden encauzar - es decir, condicionar- la interpretación de los lectores, ejerciendo un sutil pero determinante control sobre la recepción masiva de la obra. La lectura más frecuente que tiene este tipo de críticos de sor Juana es la identificación de la poeta con la figura de la escritora piadosa, una mujer entregada -intelectualmente y sin reservas- al hábito. Dado que el presente trabajo no permite mayor profundización en el tema de la crítica y recepción de la obra impresa de sor Juana, baste por el momento citar la interpretación de uno de los críticos del Segundo volumen, que incluye el Primero sueño, acaso la obra más ambiciosa de la escritora mexicana:

Gran texto me inspiró contra la madre Juana aquella memoria: Dios libre a todas mis hijas de presumir de latinas, escribe el Lapis Lydius, que previno Dios para los Agapetas de nuestro tiempo: Harto más quiero que presuman de parecer simples, que es muy de santas, que no tan rectóricas. ¡Santa mía! Muy rectórica y latina os contemplo, 
sin faltar a lo santo, con que sois la práctica solución de vuestro argumento. Esto me persuado a que vituperáis la presumpción y no la entidad. ¿Es assí? (1692, [pp. 53-54).

Bañes de Salcedo es uno de los pocos críticos en los paratextos de las obras impresas de sor Juana que invita al lector a valorar la obra con la misma libertad en el juicio crítico de que él se sirvió para aprobarla, labor que lleva a cabo ateniéndose a sus cualidades intrínsecas:

Sobresale la sabiduría en sus obras, ya dificultando y resolviendo sutil en la theología escolástica, ya explicando feliz en la expositiva, ya conceptuando ingeniosa sobre principios jurídicos, ya razonando festiva en el estilo forense, ya demonstrando evidente en la física, ya concluyendo eficaz en la metaphísica, ya enarrando cierta en la historia, ya enseñando útil en la política y ética, y ya discurriendo en las mathemáticas, en cuyas distintíssimas partes no imitó su diligente estudio la suave arte de la música ([p. 15]).

El hecho de que el crítico-censor se concentre en la sabiduría como el mayor logro de la obra -algo que no defraudaría a su autora- es un triunfo sobre la mayoría de los pareceres que se incluyen en el espacio paratextual del Segundo volumen ${ }^{15}$, que se deshacen en elogios del "raro ingenio" de sor Juana, siempre para terminar supeditándolo a la virtud y predisposición de la escritora a la santidad, cuando no predomina la sorpresa de que una mujer fuera capaz de tan "varonil erudición". La aprobación de Bañes de Salcedo resulta más decorosa que los demás pareceres que pretenden explotar al máximo la capacidad áulica de este paratexto, pues hace justicia a la obra -es decir que, al criticarla, parte del texto y no de criterios extraliterarios- y, sobre todo, lleva a cabo este ejercicio intelectual de una manera más "libre", sin la velada actitud censora con la que se condiciona la interpretación de los lectores.

Contrario a los elogios hiperbólicos que fijan en el imaginario del lector una representación de la escritora anclada en la piedad y el recogimiento -elogios que responden a la actitud de censurar la obra con cierto disimulo-, Bañes de Salcedo invita

${ }^{15}$ El Segundo volumen de las obras de sor Juana Inés de la Cruz incorpora, además de las tres aprobaciones reglamentarias, siete pareceres no legales con las mismas características compositivas que las primeras. 
al lector, de una manera poco vista en las aprobaciones, a comprobar por sí mismo la genialidad antes descrita:

Confiesso que si a esta censura no se siguiera el libro, donde los doctos hallarán fácil la prueba de lo propuesto, me contuviera el peligro de no ser creído... Siendo tales, pues, sus excelencias y ventajas, no parece se funda mal el deberse a este volumen no sólo licencia, sino mandato para que se imprima y no se arriesgue a la fatalidad del olvido una mujer, ornamento glorioso deste siglo, valiente a la república literaria y admiración perpetua de la posteridad ([pp. 15-16]).

Estas dos aproximaciones al ejercicio crítico conviven en el espacio paratextual de un mismo libro. Con frecuencia, mientras unos censores evalúan la obra a partir de criterios estilísticos o formales con una actitud crítica, otros lo hacen partiendo de intereses extraliterarios, como ocurre con algunos censores de la Inundación castálida o del Segundo volumen, que censuran sutilmente la obra haciéndola encajar en moldes preestablecidos y limitan su alcance original. Sin embargo, lo que sobresale en esta tendencia censora es la forma aparente que asume el discurso ordenador, que adopta las características del panegírico y se sirve de los mismos recursos retóricos que se utilizan en las aprobaciones "críticas". Por ello, en lo superficial, todas las aprobaciones de este período parecen dejar atrás el discurso abiertamente censorio; pero, en realidad, la necesidad de orden y censura se mantiene atada a las aprobaciones de libros hasta el momento de su desaparición en el siglo xIX, al decretarse la libertad de imprenta.

Es necesario, a modo de apunte final a la materia de la crítica literaria en las aprobaciones, aludir a un par de matices que valdría para hacer una muy necesaria distinción entre el germen de la crítica que se ve en las aprobaciones novohispanas de los siglos XVII y XVIII y la crítica literaria según se entiende en la actualidad. Si bien las características mencionadas hasta ahora -independencia del texto literario, defensa del gusto estético individual y conciencia de la heterogeneidad de la recepción- se pueden encontrar en numerosas aprobaciones de libros novohispanos, no se puede ignorar que la crítica literaria como institución surgió en el siglo xviII, y que algunos de sus vehículos de transmisión y legitimación siguen vigentes en nuestro tiempo. Según Terry Eagleton (1999), la crítica lite- 
raria moderna está en estrecha relación con la vigorización de la burguesía y su intento de liberarse del régimen autoritario, algo que se consigue por medio de diversas instituciones sociales como los clubes o tertulias, los periódicos y las gacetas. Las circunstancias de producción no son su única particularidad, sino que, esencialmente:

Se presume que dentro del espacio transparente de la esfera pública ya no son el poder social, el privilegio o la tradición los que confieren a los individuos el derecho a hablar y juzgar, sino su mayor o menor capacidad para constituirse en sujetos discursivos que coparticipen en un consenso de razón universal (p. 11).

Es evidente que esta conceptualización -que se refiere principalmente al ámbito anglosajón- debe enmarcarse en el contexto específico de la Ilustración, donde, al menos en teoría, era posible el "intercambio libre e igualitario de discursos razonables", del que habla Eagleton. En el marco de la monarquía hispánica del siglo XVII -especialmente en lo que atañe al virreinato de la Nueva España-, el principio de autonomía característico de la crítica no proviene del discurso libre e igualitario, que surge como independiente de las instituciones sociales; antes bien, a causa de la profesionalización de la crítica en el proceso de legislación libresca, se podría decir que ésta depende enteramente de las instituciones de poder. No obstante esta particular restricción para el ejercicio del juicio crítico libre -en términos modernos-, debo insistir en que el principio de autonomía, en el período que nos ocupa, se debe sencillamente a que el discurso crítico surge a partir -e independientemente- del literario, reseñándolo, valorándolo y examinándolo según distintos criterios estéticos, morales y sociales, todos ellos sujetos a las imposiciones de las distintas instituciones gobernantes.

Una buena muestra de esto es la aprobación de Pedro Calderón de la Barca a la edición de 1694 de la Cýthara de Apolo de Agustín de Salazar y Torres, publicada en España. El discurso "libre" del censor, según entendemos el ejercicio de la crítica en la actualidad, está tan supeditado a distintas instituciones -legales, sociales y artísticas- que sería imposible llamarlo un espacio "libre e igualitario"; sin embargo, el dramaturgo muestra independencia de los dictados de la institución literaria y establece distancia, no sólo en relación con la obra, sino también con su recepción masiva, para hacer un juicio propio y autónomo: 
He visto las obras póstumas de don Agustín de Salazar; y, aunque para su aprobación traían consigo los merecidos aplausos que lograron en su vida, no por esso omití examinarlas a la segunda luz, por la distancia que hay desde lo que se oye in voce a lo que in scriptis se censura; $y$, habiendo hallado en ellas, no sólo quanto imaginaba prometido, assí en lo grave de sus heroycos metros, lo dulce de los lýricos, lo apacible de los jocosos y, finalmente, lo ingenioso de sus inventivas, sin átomo que repugne a la pureza de la fe y buenas costumbres, hallo que no debe negársele a su fiel amigo D. Juan de Vera la licencia que pide para imprimirlas ([pp. 26-27]).

En los siglos XVII y XVIII las aprobaciones críticas dan cuenta de la gran responsabilidad del censor respecto de su labor de mediador entre obra literaria y público lector, debido a la rigidez de las instituciones a las que se encomienda. La aprobación de Calderón de la Barca muestra que, no obstante la opinión de los lectores -que, según indica el dramaturgo, ya habían reconocido la obra de Salazar y Torres-, algunos censores asumen el puesto de lector profesional y ofrecen un juicio estético propio, producto del gusto personal y del análisis ponderado de la obra. Este juicio es, en consecuencia, más influyente y valioso que el de cualquier grupo de lectores aficionados, principalmente por el poder que las instituciones civiles le otorgan.

\section{LOS COMPONENTES RETÓRICOS Y LITERARIOS DE LA APROBACIÓN}

Como se mencionó al inicio de este trabajo, la aprobación se constituye con base en ciertas características compositivas y formales que sugieren, más allá de la sistematización y codificación del paratexto en una suerte de "género" paratextual, su vinculación a otros géneros, como el panegírico o el tratado. Ello invita a pensar en la labor censora como un ejercicio intelectual en el que se reproducen ciertos lugares comunes, se busca embellecer el texto mediante el uso de escolios y referencias a autoridades, y se acude a imágenes y figuras retóricas que hacen que la lectura de un paratexto, inicialmente burocrático, resulte cautivadora y estimulante.

Según señala Ignacio García Aguilar (2009, p. 97) en el caso de la aprobación en el libro español, este paratexto se estructu- 
ra a partir de seis elementos constituyentes: el apartado inicial en donde se señala que el texto es una aprobación o censura, la fórmula de inicio en la que se alude a la encomienda de una institución superior, los datos del libro y el autor, la recomendación de la licencia y, por último, el lugar y fecha en que se dio la aprobación. Sin embargo, más allá de los elementos burocráticos que conforman la aprobación -pero que, sobre todo, la constituyen como documento legal-, es necesario observar cómo se relacionan, en el interior de este paratexto, la censura y la literatura. Por lo tanto, en primer lugar, propondré una descripción de la aprobación a partir de los tópicos retóricos con los que se aprueban las obras literarias -principalmente los que aluden a la importancia del autor, el tema o el elogio en que cede la censura al encomio de la obra. En segundo lugar, se intentará establecer, a grandes rasgos, cuáles son las relaciones y fricciones de las distintas preceptivas literarias a las que se acoge el censor a la hora de ejercer su juicio crítico. El estudio y clasificación de estos rasgos de las aprobaciones novohispanas está justificado porque, como señala García Aguilar, este paratexto se convirtió en un espacio flexible, abierto al análisis de la obra literaria y de las distintas propuestas estéticas, que partía del gusto individual de cada censor:

Se puede afirmar, en síntesis, que durante la época de "aprobación monotextual" (1573-1609) las aprobaciones se despojan de las ataduras formales que las determinaban en su estructura significativa y restringían su alcance pragmático. De ese modo, mediante su instrumentalización se comienza a indagar en originales e inéditas fórmulas de sanción, con las que se codifica suficientemente un espacio del libro destinado a validar al autor y a su discurso, pero no ya de acuerdo con la moral de Trento, sino con los gustos (variables) y las opciones (heterogéneas) del Parnaso (p. 100).

Las fórmulas aprobatorias de la obra literaria aparecen con frecuencia al inicio o al final de la aprobación. La totalidad de la censura no se reduce a la aplicación de un par de tópicos aprobatorios, sino más bien son éstos los que cumplen con la función performativa de aprobar legalmente el texto para su difusión impresa. Interesan, a fin de poder hablar de la aprobación como ejercicio intelectual y crítico, los tópicos retóricos y las características formales y compositivas a partir de los cuales 
la aprobación se constituye en un tipo de paratexto que comparte rasgos con otros géneros eruditos de la tradición novohispana, como los tratados y los panegíricos.

\section{LA APROBACIÓN EN VIRTUD DE LA FAMA DEL AUTOR}

En esta línea, el tópico que más abunda en las aprobaciones novohispanas de los siglos XVII y XVIII es, sin duda, el de la fama del autor. Con éste se alude a que la obra no requiere censura o evaluación gracias a la fama precedente del escritor, como se expresa en una de las aprobaciones del Panegýrico augusto de Juan Rodríguez de León (1639, [p. 6]): "leí, no una, sino algunas vezes este Panegýrico augusto, repetición devida a las obras de su autor".

Con mucha frecuencia, el tópico se refiere a las obras previas, pero ocurre también que se menciona la fama, a secas, como en la aprobación de la Vida del apóstol Santiago, donde el censor se excusa de hacer un análisis y dictamen profundo, pues "siendo tan conocido el autor, se halla desde luego supuesta la calificación de la obra" (Lezamis 1699, [p. 116]). En otras aprobaciones aparece el tópico junto con la intención de embellecer el texto crítico; así, uno de los censores de El peregrino septentrional atlante aprueba esta curiosa obra, dedicada a la vida del padre Antonio Margil de Jesús, trazando un recorrido imaginario por el proceso creador del autor, antes de repetir el tópico de su fama previa:

por ser obra que aviéndose concebido en los tersos intelectuales senos de dicho historiador y, perfeccionándose enteramente con todas sus partes, llegado el tiempo, executa a nacer a la luz pública, passando por la obscuridad de la tinta y las urgencias de la prensa con sus caracteres en el cándido lienzo del papel para ser el blanco que se lleve las atenciones de todos los sabios e insipientes que han tenido la fruición de ver los anteriores bien logrados partos [de su autor] (Félix de Espinosa 1737, [p. 21]).

Este tópico se reformula también de formas ingeniosas, pues, como muestra el siguiente parecer, el censor alude al valor de la obra por el nombre del autor y, en un intento de literaturizar el paratexto legal, justifica su declaración apologética con pinceladas de erudición: 
He visto el Panegýrico augusto de la Casa Real de España, hecho por el doctor Juan Rodríguez de León... obra que, aunque breve, tal que por ella bien se conoce ab ungue Leone, pues siendo la materia del León de las Españas, igualmente por razón que por naturaleza rey y señor dellas, tal vassallo la devió escrevir, por cierto, dignamente, pues como el nombre tiene con eminencia las propriedades de León generoso en el ánimo y admirables partes ostentadas por la superioridad del estilo, discreción y elegancia del lenguaje (Rodríguez de León 1639, [p. 7]).

Algo semejante hace el censor de la Chrónica de la santa provincia de San Diego de México (1682), de Baltasar de Medina, que recrea el tópico de la fama del autor aludiendo al valor simbólico de su nombre y lo justifica con autoridades y escolios: "Contraponía uno a otro Balthasar y... diré lo que el gravíssimo Cornelio Jansenio dixo al príncipe de la Iglesia: Simon non tam vocatis, quam es. Apóstol soberano, tu nombre es tu ser, en diziendo cómo te llamas, se ha promulgado lo que eres" ([p. 26]). El censor considera que el valor de la obra está garantizado por el nombre del autor y hace esta observación en un comentario erudito que se extiende hasta el final del folio, donde entrelaza un juego de palabras con el venerable nombre del autor (Baltasar); su apellido (Medina), que aparece en cursivas dentro de un comentario sobre la célebre ciudad libresca, Medina del Campo; y la orden a la que pertenece (religiosos descalzos), cuando alude a San Diego -la protagonista de la crónica- como una provincia "sola, descalza y pobre" $(i d$. $)$.

Si bien el uso de este tópico permite ciertas reformulaciones que dan cabida a comentarios eruditos o al embellecimiento de estos paratextos - por lo que se deduce que el censor pretende, en ocasiones, asemejarlos al texto literario-, el lugar común de la fama del autor tiene otras manifestaciones más burocráticas, en términos lastimosamente vigentes, pues también se garantiza la aprobación a partir del puesto del autor o el lugar que ocupa en alguna institución. Por ejemplo, en la aprobación de la obra de José Cabezas -la Historia prodigiosa de la admirable aparición de María santísima (1747) - se alude a la orden a la que pertenece: "Ni se podría esperar menos de quien trae consigo la recomendación de hijo de hábito del insigne convento de San Esteban de Salamanca, taller de virtud y de sabiduría" ([p. 15]); y, de manera aún más tajante y poco crítica, se libe- 
ran algunas obras de la censura por el puesto del autor, como en la aprobación del Cherubín custodio del árbol de la vida (1731): "y con decir que la escribe fray Isidro Félix de Espinosa, guardián que fue de aquel colegio y su actual chronista, eximo a la obra de censura y queda mi parecer en aprobación" ([p. 16]). No se puede ignorar que en la fórmula aprobatoria en la que se establece que la obra es más merecedora de aplausos que de censuras opera uno de los componentes más importantes del proceso legitimador de la cultura escrita: el censor no aprueba arbitrariamente la obra porque su autor pertenezca a un colegio de su agrado; antes bien, reconoce que su labor está sujeta a la deferencia incuestionable hacia determinadas instituciones y que la autoridad de ellas está por encima de su propia potestad como censor.

Estas distintas formalizaciones del tópico -en la extensión, tono y estilo- muestran que la aprobación no era sólo un espacio abierto a la reflexión de los méritos conseguidos por la obra literaria, sino también un paratexto que permitía, de alguna manera, la experimentación del propio crítico con los distintos componentes retóricos establecidos por la nueva, aunque manifiesta, tradición paratextual. Ya sea en el uso del tópico de la fama del autor, como en el de la pertinencia del tema-e, incluso, en el elogio-, algunos censores buscarán la originalidad y el artificio en oposición a la repetición mecánica de lugares comunes.

\section{TEMAS Y GÉNEROS QUE MERECEN APROBACIÓN}

El segundo tópico más frecuente en las aprobaciones es aquel por el que se aprueba la obra gracias al tema que trata; y, sin duda, el tema religioso es el que con mayor frecuencia merece aprobación sin necesidad de crítica o censura. Es importante retomar, en este punto, la consideración de que los géneros literarios en la Nueva España y su circulación están condicionados por la visión evangelizadora y forjadora de una nueva sociedad cristiana en el territorio americano. La necesidad de producir textos edificantes en la Nueva España se refuerza en el proceso legitimador de las aprobaciones de libros; y, nuevamente, el juicio crítico y ponderado de los censores se supedita a lo intocable: en este caso, los géneros y materias que contribuyen al proyecto ideologizador de la Corona española. 
La obra poética Desagravios de Christo en el triunfo de su corazón contra el judaísmo se aprueba por sus logros estéticos, aunque "más por el asumpto argumentoso, que con el espíritu de san Pablo intenta... en quitar a los judíos con su mesma ley mal entendida los velos caducos que tienen puestos sobre sus coraçones ciegamente endurecidos y pertinazmente obstinados" (Corchero Carreño 1649, [p. 5]). La cuarta y última aprobación de este libro reproduce el mismo tópico y se apega más a la retórica propia del texto encomiástico:

téngolos leýdos y no sólo no he hallado qué corregir, pero le agradezco lo que me ha ocasionado aprender obra tan suya que lo dice la dulçura: el assumpto es tan piadoso que se roba las atenciones, él dejará bastantemente acreditado [a] su autor. ¿Quién, pregunto, advirtiendo el título (aunque no sea curioso) no solicitará la obra? ([p. 19]).

La alusión a que sólo el título de la obra basta para aprobarlo, aun sin conocer siquiera el tema, es muy frecuente en las aprobaciones novohispanas, como se ve en la del libro Historia prodigiosa de la admirable aparición de María santísima: "Assí obligado, dixe desde luego, que sólo con ver el título de la obra me inclinaba a dar mi sentir a su favor" (Cabezas 1747, [p. 26]). El tópico aprobatorio del valor del tema era imitado a conciencia por los censores. Algunos -como el que aprueba las Nuevas empresas del peregrino americano septentrional atlante, que es la continuación de la vida del padre Antonio Margil de Jesús- no pueden dejar de reproducirlo, aunque con pequeñas variaciones que incluyen hipérboles un poco más ingeniosas que las de sus precursores. El censor Juan Crisóstomo Martínez comienza la aprobación expresando sus dudas sobre la novedad de esta obra aludiendo, precisamente, a su título: "Y cierto que sobre mi respectoso aprecio me hazía dudar de esta obra la propriedad del título, y a mis solas decía: ¿es posible que todavía es atlante el venerable padre fr. Antonio Margil?" (Félix de Espinosa 1747, [p. 10]). Después de una erudita reflexión sobre los logros de algunos personajes mitológicos -con quienes compara al sacerdote que protagoniza esta biografía-, se replantea la duda inicial y vuelve a prestar atención al título, merecedor por sí solo de aprobación por sus ecos literarios y religiosos: "así dudaba, pero atendiendo mi veneración al epíteto que se le añade a aqueste atlante, llamándolo juntamente peregrino, hallo mi com- 
placencia en lo alusivo de este nombre y en el estilo con que trata el author este material, multiplicadas las propriedades" ( $i d$. .).

Otros censores empiezan también la crítica de la obra aludiendo a su experiencia como lectores y, en el caso del siguiente, no le basta acudir a un tópico aprobatorio para comenzar su reflexión o análisis, sino que reúne en una frase tres de los más frecuentes: el valor del autor, la importancia del tema y la necesidad de elogiar la obra, más que censurarla:

Y assí continué interesado la diligencia de seguir su lección [de la obra] hasta fenecerla, no tanto por obligación de censor quanto por ambiciosa curiosidad de aplicado; $y$, dexando por supuesta en sólo el nombre del autor la más authéntica, ilustre y segura aprobación de la obra, passaría gustoso a sus elogios, si confiasse tanto de mi pluma como concibo de mi obligación a exercitarla en ellos por su assumpto, pues [es] éste el aplaudir las prodigiosas virtudes de la gloriosa virgen santa Rosa (Oviedo y Herrera 1729, [pp. 14-15]).

\section{El CARÁCter ÁUlico de LA AProbACión}

Otro de los tópicos frecuentes en las aprobaciones novohispanas es el que, como se lee en el ejemplo anterior, declara que la obra es más merecedora de elogios que de censuras. Éste figura también en numerosas aprobaciones españolas, según apunta Alain Bègue (2009, p. 96), aunque, a diferencia del panorama español, en las aprobaciones novohispanas hay pocas alusiones al problema que el elogio supone para el ejercicio autónomo de la crítica. No se puede ignorar que, en la tradición de este paratexto en la Nueva España, el elogio es un recurso imprescindible para la formalización de la función apologética, ya que, como mencioné al principio del presente trabajo, esta función está en estrecha relación con el propósito del censor: la necesidad de promover la obra más que censurarla. En este sentido es necesario recuperar la aseveración de Robert Darnton (2014) de que la censura previa servía como una "ratificación real", más que como un mecanismo de prohibición: "The book was a quality product, it had a royal sanction, and in dispensing that sanction, the censor vouched for its general excellence. Censorship was not simply a matter of purging heresies, it was positive -a royal endorsement of the book and an official invitation to 
read it" (p. 29). Ver la censura previa como una ratificación que las autoridades hacían de la palabra escrita ayuda a enmarcar el discurso crítico-apologético de la aprobación en un trabajo intelectual, en el que el censor asume la responsabilidad de promover las obras merecedoras de admiración y elogio para su lectura y valoración masiva. Esto se aprecia en la gran mayoría de las aprobaciones estudiadas, de las cuales citaré tan sólo unos ejemplos.

El sentir de Rodrigo de Medinilla a los Desagravios de Christo, titulado sencillamente "Carta al autor", es un paratexto crítico con todas las características de la aprobación -sin serlo, pues no otorga la licencia de impresión, como comenté anteriormente-; tanto así que muestra el ya mencionado desplazamiento retórico de la aprobación burocrática al elogio del autor, una práctica que responde a las normas de cortesanía de sus contemporáneos, pues justifica su dictamen favorable con declarar: "con sobrado motivo, si me escuso a la censura, me rindo a la admiración"; y, para cerrar el texto, usando una fórmula similar a la del censor, reitera: "esto siento, y no menos que a esta obra sobran mis aplausos cuando son tan ciertos los de todo el reyno" (Corchero Carreño 1649, [p. 10]).

La aprobación de Tomás Montaño a las Letras felizmente laureadas y laurel festivo de letras (1724) de Cristóbal Ruiz Guerra y Morales, una colección de poemas que se publicó con ocasión de la jura del rey Luis Fernando I, inicia con el tópico del elogio sobre la censura, al mismo tiempo que retoma otros tópicos aprobatorios como el del valor intrínseco del tema. Sin embargo, en los primeros párrafos de esta aprobación destaca la evaluación del estilo de la obra, que es algo infrecuente, ya que, por lo general, es aquí donde se acude a la repetición de alguno de los lugares comunes antes mencionados:

Y brillando desde luego en la frente del libro lo soberano del assumpto, lo peregrino de la idea, lo heroyco de los poemas, engastados con delicados hilos de subtil filigrana en una artificiosa corona, ¿quién no conoce lo emphático del decreto, que en vez de censura y revistas, me intima reconocimientos? ([p. 30]).

No obstante, para introducir el elogio, la mayoría de las aprobaciones incluye una sencilla y práctica fórmula al inicio o al final del paratexto, algo que se puede ver en la tercera aprobación de la Vida de Santa Rosa de Lima, en donde el doctor don 
Pedro de la Peña declara: "Constitúyeme V.S. juez de tan consumada obra, y siendo tan grande la circunspección que requiere este oficio, me veía precisado a reservar un oído para la censura, deseándolos tener ambos libres para el aplauso" (Oviedo y Herrera 1729, [p. 31]).

Algunos censores llevan el elogio más allá de las normas de cortesanía y sustentan el encomio de la obra en el afecto que el censor tiene por el poeta o su relación personal o familiar, como se deja ver en la aprobación de Lucas del Rincón a la obra $\mathrm{El}$ peregrino septentrional atlante, de la que he citado ya otras aprobaciones. En ésta, el censor concluye su evaluación, diciendo: "y yo me detuviera muy gustoso en aplaudir los aciertos de su author, si no fuera tan interesado en sus elogios: pues sobre el vínculo de la sangre que nos estrecha, el amor se adelanta un grado más, uniéndonos como hermanos. Y assí puede V.S., siendo servido, conceder la licencia" (Félix de Espinosa 1737, [p. 20]).

Resulta un tanto incongruente la trabazón del elogio -sobre todo cuando lo motivan razones tan arbitrarias, como la relación personal con el autor- con la idea de que la labor del censor es ofrecer un juicio imparcial y ponderado de la obra que atienda a sus logros artísticos. Pero, como se sugirió anteriormente, es necesario tener en cuenta que los lugares comunes y tópicos que se consagran al elogio no invalidan el ejercicio del juicio crítico individual del censor; antes bien, dado que parte de su trabajo es consagrar la obra analizada -mediante dichos tópicos- a la aceptación de la institución literaria que ellos presiden, el elogio resulta ser un magnífico complemento a la función crítica de la aprobación.

\section{LA ADSCRIPCIÓN DE LA OBRA LITERARIA A UNA POÉTICA DETERMINADA}

De todos los componentes de la aprobación que se exponen en este trabajo, ninguno contribuye tanto como la función preceptiva a la constatación de que la aprobación de libros se abrió, en los siglos XVII y XVIII, al ejercicio intelectual y erudito. Esta función se observa, casi sin excepción, en todas las aprobaciones de textos literarios novohispanos, y frecuentemente se alinea con la polémica literaria a propósito de la poesía cultista o gongorina, que "se centró en dos polos literarios, oscuridad-claridad, los cuales obligaban a adoptar una postura teórica" (Ontañón 
de Lope 1991, p. 1142). Es de esperar que este paratexto, en cuanto que contiene un discurso crítico-apologético, refleje la opinión del censor sobre la adecuación de la obra a una de estas dos posturas.

La dicotomía claridad-oscuridad, que polarizó a críticos y poetas durante buena parte del siglo XviI en España, tiene como antecedente el enfrentamiento de dos posturas teóricas y estéticas en la Italia del Cinquecento: la postura clásica heredera del Renacimiento se encuentra con la oposición de la nueva estética anticlasicista, defensora del furor creativo del poeta y detractora del principio de imitación y utilidad. Este enfrentamiento se da no sólo en el ejercicio de creación literaria, sino en numerosos tratados de poética que desarman la tradición aristotélica, como el de Franceso Patrizi o, ya en el siglo XVII, el del polémico Giambattista Marino. La preceptiva barroca culmina en España con Gracián, cuya Agudeza y arte de ingenio (1642 y 1648) es un tour de force que no encuentra parangón, ni antes ni después del Barroco (Snyder 2014, p. 74).

La influencia de Gracián -especialmente en su definición del concepto y la defensa que hace de la dificultad interpretativa del texto- alcanzó las primeras décadas del siglo xviII en la Nueva España, donde más de una centuria después de la publicación de su tratado, y en un momento en que la Metrópoli había superado la barroca afectación del estilo, los censores de libros novohispanos seguían sopesando los logros de las obras en función de la idea graciana de que el concepto es más que un adorno superficial, algo que cumple una función filosófica con el empleo de figuras retóricas y poéticas; pues Gracián combate la idea, muy extendida en el siglo XviI, de que el concepto es sólo un artificio del lenguaje vacío de sentido; para él, el concepto es un estímulo estético e intelectual (Gracián 1725, p. 2).

No obstante la dilatada presencia de la poética barroca en la Nueva España, la clásica de Aristóteles y Horacio está, en realidad, muy presente en las aprobaciones, particularmente el principio clásico de utilidad. Las aprobaciones analizadas en este trabajo pertenecen a los preliminares de libros de poesía, novelas, vidas de santos -o biografías- y crónicas. Si bien la clasificación de los últimos dos géneros como literatura presenta un problema en la actualidad, la crítica en las aprobaciones de estos libros se sustenta en planteamientos teóricos que no pueden considerarse más que retóricos y literarios: 
Y si el motivo mejor para leer es el dichoso fin de aprovechar, como dice san Ambrosio: Legimus aliqua, ne negligantur, legimus ne ignoremus; quien leyere con zelosa aplicación aquesta historia aprenderá las máximas más seguras de mejorarse en la vida; porque las mejoras de una vida reverberan como en un espejo en las luzes de una historia: Tanquam in speculo, dice Platón, ornare $\mathcal{E}^{\circ}$ comparare vitam tuam ad alienas virtutes stude; y si quisiere también el historiador admirar las reglas más ciertas para escribir, en esta historia las veerá bien claras para imitar. No debe, dice Policiano, el historiador desatar todos los copiosos raudales de su eloquencia para exornar de tropos, figuras, periodos y de otras impertinentes alusiones, como algunos imaginan, las planas ajustadas de sus historias: Nihil est magis dedecens $\mathcal{E}^{2}$ noxium in omni materia, in qua agitur de vero cognoscendo, quam universum dicendi genus elaboratum; y con razón, porque si donde la historia sobra, falta la juventud con su vejez; donde se falta a las reglas maduras de la vejez, sobrará sin duda la juventud (Félix de Espinosa 1731, [pp. 14-15]).

Algunos libros de historia o crónicas obtienen aprobaciones que aluden a la utilidad de la obra, no sólo por el aprendizaje al que invita la materia, sino también porque permiten al lector aprender un estilo sobrio y mesurado, fundamentado en los registros antiguos y las autoridades. Como muestra la aprobación anterior, el censor contrapone la literatura imaginada -llena de tropos, figuras y períodos impertinentes- con la que se apoya en la verdad histórica, de donde podrá el lector aprender “máximas más seguras de mejorarse la vida”. Dependiendo, pues, del género, el censor acudirá a una poética registrada en su imaginario y bagaje cultural para poder hacer un juicio crítico de la obra.

Las obras de tema religioso son las que con mayor frecuencia se evalúan en términos de su utilidad para el lector devoto. Sin embargo, contrario a lo que expresan las aprobaciones de libros religiosos en prosa, cuando la obra comentada es poesía, el censor se acoge a la poética clásica de Horacio para argumentar su crítica: "Lo tercero que hallo es que doctrina tan devota la haze más agradable y suave en proponerla en el poema heroyco que propone, para que todos la gozen, pues la poesía, dixo un poeta latino y moderno que era tan regalada y bien recebida como el blando y regalado zéphiro" (Corchero Carreño 1649, [p. 8]).

La idea de mezclar lo agradable con lo útil, "deleitando al lector e instruyéndolo a un tiempo” (2008, p. 404), en palabras 
de Horacio, aparece en numerosas aprobaciones de libros de poesía y no necesariamente polariza la opinión crítica del censor. Es decir que aun cuando los autores de tratados del Barroco plantearon una función de la literatura distinta a la de utilidad, en las aprobaciones de libros en Nueva España no hay rechazo de la poética clásica en este aspecto, sino más bien la integración de muchos de sus preceptos a las directrices más "modernas"16, como se puede ver en una de las aprobaciones del Panegýrico augusto, donde el censor exalta tanto el apego de la obra a la poética clásica del docere-delectare, como el deleite que ofrece la poesía conceptista:

Y como las asperezas dificultosas de la virtud piden salsa sabrosa para comerse y dulçura de palabras que las facilite, busca para esto, no sólo abrigo a la verdad, sino también deleyte a los oyentes para poderla mejor escuchar, usando de una retórica tan pura para aprender como conceptuosa para aprovechar (Rodríguez de León 1639, [p. 17]).

La primera aprobación que autoriza la publicación de la novela pastoril los Sirgueros de la Virgen, a cargo de fray Victoriano de Esmir, ejemplifica con mayor claridad esta conciliación entre poéticas aparentemente contradictorias y, lo que es aún más interesante, muestra cómo la misma obra puede tener una lectura y una recepción distintas según los gustos y las necesidades del lector. Para el censor, según expresa en la aprobación, el poeta es un tipo de lector que busca la dificultad del concepto y la oportunidad de poner su agudeza a prueba; el lector curioso, por su parte, busca el deleite, algo que no anula el principio de utilidad, más adecuado para la lectura del erudito; y, por último, esta novela pastoril puede también servir como entretenimiento para el rústico pastor. Por ello, según la opinión del crítico-censor, en la obra se ponen en práctica distintas preceptivas y, por tanto, es posible que todos los lectores encuentren en ella algo valioso:

Remitióme V. Excelencia (señor excelentísimo) el libro intitulado los Sirgueros de la Virgen sin original peccado que compuso el bachiller Francisco Bramón, y aviéndolo visto y examinado,

16 Marcando la distancia del sentido actual de la palabra, según JoN R. SNYder (2014, p. 29), los artistas barrocos se llamaban a sí mismos "modernos". 
hallo que su dulce canto es digno se celebre, pues en él (como en copiosa silva) hallará el poeta realçados conceptos, el curioso en qué deleytarse, el sabio qué advertir y el pastor sencillo canciones con qué entretener la soledad del prado (Bramón 1620, [p. 11]).

El concepto -según lo entiende Gracián- muestra la correlación entre elementos que se sitúan uno junto al otro y resaltan su relación dentro del contexto de la obra. En esta aprobación - como en otras que también elogian el uso del concepto-, el censor sólo identifica y señala la obra como conceptista sin indagar demasiado en lo que esto supone; sin embargo, "el concepto modera la diferencia entre el Barroco y la tradición" (Snyder 2014 , p. 67), por lo que merece la pena indagar en las relaciones y discrepancias entre las preceptivas clásica y barroca, aparentemente enfrentadas. Como he insistido anteriormente, el principio de utilidad es el recurso fundamental del censor para adscribir la obra a la poética clásica; sin embargo, se utiliza casi exclusivamente en las aprobaciones de libros de tema religioso -y de manera excepcional en las crónicas-, ya sea en poesía como en prosa. En la segunda aprobación de Los sirgueros de la Virgen se puede leer:

Vi este libro, título Sirgueros de la Virgen, autor el bachiller Francisco Bramón y además de no haver en él cosa que desdiga de nuestra sancta fe cathólica y buenas costumbres, es útil para que las almas devotas tengan con qué aumentar su devoción y entretenerse honesta y sanctamente (cosas que pocas vezes se hallan juntas en una misma obra). Y assí juzgo que se le deve dar la licencia que para imprimir pretende (Bramón 1620, [p. 12]).

Algo distinto ocurre con otra novela pastoril novohispana de la década anterior. Siglo de oro en las selvas de Erifile, de Bernardo de Balbuena, se publicó en 1608 en Madrid con numerosos poemas laudatorios de los más célebres poetas del siglo, como Lope de Vega y Quevedo. Aunque igualmente es breve, el principio de utilidad -y cualquier otro fundamento de la poética clásica- se ve desplazado en esta aprobación por dos elementos esenciales de la preceptiva barroca: el ingenio y el estilo, que el crítico llama "curioso", lo que se puede atribuir a que la obra no es de tema religioso, y también, quizá, a que la censura se encomendó a un escritor, Tomás Gracián Dantisco: 
Por mandado de V. Alteza he visto este libro, intitulado Selvas de Erifile, del doctor Bernardo de Balbuena, y assí por no tener cosa que ofenda como por ser de ingenio y apacible y del estilo de otros curiosos libros que andan deste lenguaje y traça, se le puede dar al autor la licencia y privilegio que suplica (Balbuena 1608, [p. 7]).

El estilo de la obra, que pretende imitar a Teócrito, Virgilio y Sannazaro, como se registra en el título de la novela, difícilmente podría considerarse conceptista; más bien reproduce los tópicos renacentistas de la égloga y la novela pastoril. Sin embargo, la atención del crítico-censor al estilo y la clasificación de la novela como perteneciente a un grupo de obras de determinado "lenguaje y traza" -en oposición a algo más normativo o clásico-sugiere que está evaluando la obra en términos de la originalidad que comparte con obras similares.

No obstante, en las aprobaciones novohispanas abunda la contraparte del tópico del ingenio del autor, heredero de la preceptiva graciana: el "arte" o la técnica que expone la poética de Horacio es con mayor frecuencia la responsable del éxito obtenido por el autor. En la visión del poeta y preceptista latino no son tan importantes "las cualidades que ha de tener la obra acabada como... los presupuestos con los que el poeta debe contribuir a ese fin: su esmero, su esfuerzo, su dedicación" (Fuhrmann 2011, p. 225). Para muchos críticos y censores de libros en la Nueva España, cualquier logro estético, erudito e intelectual debe atribuirse al trabajo del autor o, en todo caso, a la técnica perfeccionada a lo largo del tiempo:

Al largo seguir de aquellas obras añade otro en las suyas el author de este libro, quien se ha mostrado tan infatigable que, no contento con haver los años passados escrito la vida del ven[erable] padre con aquella dilatación, que pudo ofrecerle lo apressurado del tiempo en un libro que con tantos aplausos recibieron la devoción y la cultura, aun todavía prosigue constante el mismo intento, duplicándolo gratamente en número correspondiente a las dos vezes (Félix de Espinosa 1747, [p. 12]).

Con mucha frecuencia son las obras que tienen un sustento erudito las que adscriben el éxito de la obra al esfuerzo. Según señalé con anterioridad, las novelas pastoriles -uno de los escasos ejemplos de prosa de ficción en la Nueva España- y algunas obras poéticas recibían aprobaciones en las que se elogiaba 
el ingenio innato del escritor, mientras que una obra como la Chrónica de la santa provincia de San Diego de México, de Baltasar de Medina, llama la atención del censor por el esfuerzo dedicado a la investigación y anotación marginal: "El juizio lo publica el seso de la obra, el tesoro lo erudito de la narración. En sus apuntamientos marginales se descubre mucha riqueza escondida y ganada al sudor y aflicción de afanados estudios en todo género de buenas letras" (1682, [p. 23]).

No es descabellado afirmar que, como ocurre con el principio de utilidad clásico, la concepción horaciana del arte como técnica que debe ser perfeccionada aparece en las aprobaciones de obras eruditas que prestan más atención a la autoridad que a la innovación. Coincidentemente, algunos censores utilizan el tópico por excelencia del trabajo diligente y exquisito -el de la abeja-, para reconocer la labor mesurada del escritor: "trabajado en esta obra como solícita abeja, de quien dixo el Ecclesiástico que en la labor de su miel operaria est, operationem quoque venerabilem facit" (Corchero Carreño 1649, [p. 8]). Pero como en todo hay excepciones, este lugar común aparece también al comentar la confección estilística de la poesía, aunque siempre en relación con el principio de utilidad:

y [no] olvide en estos [versos] el consejo de Ysócrates, que persuadía que en este género de lecciones debía el estudioso proceder a imitación de la misma abeja, que reconoce estudiosa y advertida todas las flores, sin perdonar el más prolijo examen de alguna de ellas, pero chupando de cada una sólo la parte útil, pues en este vergel hermoso, en que cada palabra es fértil, segura semilla a que corresponde copiosa, estimable cosecha... ninguna se hallará que no abrigue y encierre muchas utilidades (Oviedo y Herrera 1729, [pp. 23-24]).

Por lo demás, respecto de la concepción preceptiva del estilo en las aprobaciones, sería imposible comentar extensamente cómo cada censor hace una crítica de la obra a partir de alguna poética clásica o barroca. Sin embargo, es posible en líneas generales determinar dos tendencias. En primer lugar está aquella en que se valora el conceptismo y la dificultad interpretativa; y, en segundo, la del estilo sobrio y simplificado, heredero de la poética clásica y respuesta a la oscuridad propia del mal llamado "culteranismo". El primer estilo, aún barroco y muy característico de la literatura hispánica, celebra la posibi- 
lidad de crear imágenes ricas y elaboradas, aptas para un lector avezado en la agudeza graciana y dispuesto a asumir el reto y el deleite que supone la dificultad, puesto que "toda dificultad solícita -dice Gracián- es discurso y es agradable pasto del ingenio; con la proposición suspende y con la ingeniosa salida satisface" (1967 [1648], p. 421). Naturalmente, esta dificultad adquiere la forma del concepto que, bien logrado, resulta claro, coherente y despejado de oscuridad, tal como muestra el comentario del censor de la Vida de Santa Rosa de Lima:

lo expresivo y conceptuoso, lo ameno y bien significado, corriendo la pluma tan libre por entre la ajustada prensa del verso, como pudiera apenas otro, por entre la licenciosa libertad de la prosa y esto, no ya fabricando qual artificiosa abeja, geroglífico de la poesía, este dulcísimo panal de las más proporcionadas acciones de la santa a las metáphoras, figuras y conceptos, sino hallando a todas sin elegirlas, escogidas galas y vistosos matizes con qué hermosearlas; y lo que más es, sin desviarse un punto de la obligación de historiador ni de los preceptos de poeta (Oviedo y Herrera 1729, [p. 22]).

Este poema heroico, aunque del Barroco tardío, fue muy celebrado y reimpreso en Perú, Nueva España y España. No se puede decir lo mismo del estilo de todas las obras conceptistas novohispanas, por lo que muchas aprobaciones alaban las virtudes contrarias al estilo conceptista -la mesura y sobriedad-, ya que la hiperbarroquización, que vino a dar en el uso excesivo de erudición, oscuridad en el estilo y conceptismo impenetrable, se consideraba un exceso del lenguaje. Así, muchas aprobaciones aluden a la claridad como un logro estético y estilístico del autor:

Y no menos pudiera aplicarle al author desta obra lo que dixo S. Gregorio Nazianzeno a Themistio: Tu rex es sermonum. Eres tan naturalmente elegante y con tanta facilidad claro, que todo te lo hallas dicho; hablas con imperio, sin tiranizar las palabras, ni violentar las sentencias, conviniéndole lo que de un gran ingenio dixo Sidionio: Curce fiunt causam potius implere, quam paginam (Ribera 1673, [p. 13]).

El censor de la Breve relación de la plausible pompa y cordial regocijo, de Diego de Ribera, considera que el estilo de la obra es claro porque no hay perturbaciones excesivas del lenguaje. 
En cierta medida se puede decir que a finales del siglo XviI la subversión del uso natural del lenguaje en búsqueda del concepto no era ya un ejercicio poético mesurado, por lo que no resulta extraño que en gran parte de las aprobaciones de finales del siglo XVII y principios del XVIII se teorice sobre la claridad como la contraparte moderada de los excesos estilísticos del Barroco tardío. Algunas aprobaciones acuden a las autoridades clásicas para ejemplificar el estilo conciso, en particular a Séneca:

me detiene la pluma en las dignas alabanzas que se merece el author de aquesta obra tanto más digna de alabanza, quanto más compendiosa y reducida, según sentir de Séneca, quien gradúa la magnitud de los artífices por lo abreviado de sus reducciones: Magni artificis clausisse totum in exiguo (Cabezas 1747, [p. 24] ${ }^{17}$.

En los comentarios críticos sobre el estilo, así como en lo que respecta a la función de la literatura (utilidad vs. deleite) y al principio creativo del autor (ingenio vs. técnica), es imposible determinar una pauta unívoca en el apego a una preceptiva por encima de la otra. Cualquier polarización a la hora de interpretar las reflexiones teóricas de los críticos de este período es problemática, ya que la preceptiva barroca -en su repertorio teórico extenso e irreductible- no pretende hacer tabula rasa con la teoría poética de la antigüedad: tanto en la Metrópoli cuanto en la Nueva España, la tradición culta, despectivamente llamada "culterana" por sus contemporáneos, prolonga hasta inicios del siglo XVIII su vínculo con el mundo clásico y, aunque luego se tildó de abigarrada y superficial, los elementos teóricos que se utilizan para derribarla provienen también de la autorizada poética de Horacio.

Ante la imposibilidad de desentrañar todas las fricciones entre el clasicismo y el Barroco que se dieron a lo largo del virreinato, basta por el momento revelar la forma en que ambas preceptivas aparecen reflejadas en las aprobaciones estudiadas hasta ahora. El patrón que se observa en el extenso período que comprende esta investigación -pues se han estudiado aprobaciones que van desde la de Siglo de oro en las selvas de Erifile, de Balbuena (de 1608), hasta obras de la primera mitad del

17 La cita en latín de las Epístolas morales a Lucilio está incompleta; textualmente sería: "magni me hercule articificis est, clausisse totum in tam exiguo” (III, 53, §11; 2010, t. 1). 
siglo XVIII- es que la elección de ciertos temas o géneros, como el religioso o el histórico, determinan la adecuación del estilo del autor a ciertas normas y preceptos teóricos que el censor comenta diligentemente en la aprobación.

En líneas generales, una obra de tema religioso se aprueba en virtud de su utilidad para moldear comportamientos, así como frecuentemente la poesía se juzga por el deleite que ofrece al lector. Lo mismo se puede decir de la génesis creativa de la obra: el ingenio propio de la poética barroca se aprecia como motor creador de obras de entretenimiento y poesía, mientras que la erudición -que, naturalmente, inunda también numerosas obras poéticas- se atribuye comúnmente al esfuerzo y la técnica del escritor. En los comentarios sobre el estilo, por último, se aprecian tendencias semejantes: sólo en la poesía se permite la osadía formal dentro y fuera del concepto, mientras que, en las obras eruditas, históricas o de tema religioso, el censor valora la claridad, noción derivada de la preceptiva clásica.

Esta adecuación de las poéticas a los distintos géneros literarios en la aprobación refuerza la idea planteada al inicio de este trabajo, aquella de que los críticos y censores -los autores de las aprobaciones- llevaban a cabo, como hombres de letras, una labor intelectual que consistía en ratificar y promover determinadas obras a partir de sus distintos valores estéticos: tanto formales, cuanto de contenido. La función intelectual de la aprobación es la crítica y apología del texto central que se deja ver en los comentarios sobre preceptiva literaria de los censores; y más allá de buscar en su configuración genérica una serie de tópicos y características formales y de contenido, el elemento distintivo de este paratexto es el complejo entramado que se crea entre el discurso apologético e intelectual y el papel que éste desempeña en la censura.

\section{CONCLUSión}

Después de dos siglos de tradición crítica en las aprobaciones de libros, lo cual sugiere -al menos superfluamente- que la antigua función de la censura había quedado reducida a una mecánica frase aprobatoria, se puede observar que esta función se diluye y se adapta al discurso crítico y apologético, pero no desaparece. En el plano discursivo, la censura permanece en aprobaciones aparentemente "críticas", como en el caso de las 
obras de sor Juana Inés de la Cruz, donde las interpretaciones que favorecen lecturas conservadoras de la monumental obra sorjuanina conviven con acertados análisis que no rehúyen su complejidad. Pero esta vertiente no sólo se encuentra en ejemplos como el anterior; también es frecuente, como se vio en el apartado dedicado a los tópicos aprobatorios, que el juicio crítico y ponderado de la obra se supedite a instancias mayores, como los diversos cauces que encuentra la incuestionable autoridad de las instituciones civiles y religiosas. Por eso sucede que, en un gesto en apariencia contradictorio con el ejercicio crítico e intelectual, los censores aprueben sin reparos algunas obras en virtud de la materia, de la fama del escritor o de su pertenencia a tal o cual institución.

Sin embargo, sería un error creer que incluso las aprobaciones en las que se lleva a cabo un juicio crítico independiente no están supeditadas a alguna forma de poder. Como apunta Robert Darnton (2014, p. 19), toda palabra hablada o escrita ejerce poder, pues el poder del discurso opera de modos que no son fundamentalmente opuestos a las acciones ordinarias del mundo; más allá de ver la censura como la violación de un derecho, habría que considerarla como ingrediente omnipresente de la realidad social, sobre todo en el período estudiado. Incluso cuando los censores ejercen su juicio crítico para sopesar los logros de la obra sujeta a dictamen, lo hacen siguiendo determinados preceptos estilísticos y literarios previamente aprobados por la tradición, como se deja ver en el apartado dedicado al análisis de las preceptivas literarias, que se engarzan soberbiamente con los distintos recursos retóricos que conforman este paratexto.

La evolución de la aprobación hacia lo que se ha considerado el germen de la crítica literaria en el mundo hispánico no es, en Nueva España, un impedimento para que los agentes de la institución literaria -vinculados invariablemente con las instituciones religiosas y civiles del virreinato- siguieran ejerciendo un control sutil, aunque determinante, sobre la cultura escrita a lo largo de los siglos XVII y XVIII ${ }^{18}$. Es precisamente dentro

18 El uso de la crítica y el panegírico en la aprobación se extiende, hasta lo que podríamos considerar excesivo -con censuras o pareceres de hasta 30 páginas-, en el siglo XVIII. El imperativo de incorporar siempre la aprobación o censura previa en los preliminares del libro se mantuvo hasta que se decretó la libertad de imprenta y se prohibió tanto su impresión como la de las poesías preliminares en los umbrales del texto. 
de esta tradición discursiva iniciada en el espacio paratextual que se deja ver la velada pero firme autoridad que los censores tenían sobre el discurso crítico de la obra y la figura del autor cuyo trabajo buscaban promover. Si bien en los propios fundamentos de la aprobación como ejercicio crítico está sutilmente imbricada la necesidad de control, autorización y censura, no se puede pasar por alto que ambas posturas son complementarias en este período, y que estudiar estos paratextos nos permite acercar la mirada a un tipo de práctica intelectual propia del Barroco que es difícil de asimilar en la actualidad: la de una lectura crítica, anclada en la interpretación de diversas preceptivas literarias, que invita también a la reproducción de recursos retóricos y literarios -con el propósito de embellecer el texto crítico-censorio-y que, simultáneamente, responde a la necesidad de control de las instituciones civiles, religiosas y de la misma institución literaria, cuyos intereses estaban en sintonía con las distintas instancias de poder, como invita a pensar Ángel Rama (1998, p. 32).

En el marco de este complejo aparato de crítica y autorización en los preliminares del libro se puede observar, por consiguiente, una circularidad un tanto paradójica: considerando el aspecto material, la aprobación es un documento secundario, un accesorio del texto central y, a su vez, un elemento imprescindible para la propia existencia del libro impreso. Esta circularidad se puede observar, también, en el plano textual: la aprobación -en cuanto que paratexto- es un discurso periférico respecto de la obra y, simultáneamente, un importante instrumento para la ordenación del libro, a causa del poder que el censor tiene sobre la interpretación, clasificación y difusión del texto. Este poder sobre la ordenación del discurso es lo que nos permite hablar de la aprobación como un importante instrumento de institucionalización literaria. Porque es mediante la aplicación de la preceptiva poética para la valoración estética de la obra que se obtiene el permiso burocrático necesario para la existencia material del libro impreso. En la Nueva España, la poesía, las novelas, las vidas de santos y las crónicas se imprimieron y difundieron después de que los agentes de la institución literaria las hubieran evaluado a partir de ciertos criterios de composición estéticos e intelectuales. Estos criterios se negociaban con las autoridades en un documento aprobatorio que contaba con sus propias reglas de composición de indudable raigambre humanística. 


\section{REFERENCIAS}

\section{Corpus}

Balbuena, Bernardo de 1608. Siglo de oro en las selvas de Erifile, Alonso Martín, Madrid.

Bramón, Francisco 1620. Los sirgueros de la Virgen, s.e., México.

Cabezas, José 1747. Historia prodigiosa de la admirable aparición de María santísima, Imprenta de Nuevo Rezado, México.

Corchero Carreño, Francisco 1649. Desagravios de Christo en el triumpho de su cruz contra el judaísmo, poema heroico, Juan Ruiz, México.

FÉlix DE EsPinosa, Isidro 1731. El cherubin custodio del árbol de la vida, José Bernardo de Hogal, México.

FÉliX DE EsPinosA, IsIDro 1737. El peregrino septentrional atlante, José Bernardo de Hogal, México.

FÉLIX DE EsPinosA, Isidro 1747. Nuevas empresas del peregrino americano septentrional atlante, Imprenta del Nuevo Rezado, México.

Juana Inés de la Cruz, sor 1692. Segundo volumen, Tomás López de Haro, Sevilla.

Lezamis, José de 1699. Vida del apóstol Santiago el mayor, Doña María de Benavides, México.

Medina, Baltasar de 1682. Chrónica de la santa provincia de San Diego de México, Juan de Ribera, México.

Oviedo y Herrera, Luis Antonio de 1729. Vida de Santa Rosa de Lima, poema heroyco, Miguel de Ribera Calderón, México.

Ribera, Diego De 1673. Breve relación de la plausible pompa y cordial regocijo, Viuda de Bernardo Calderón, México.

Ribera, Diego De 1684. Concentos fúnebres, métricos lamentos, Viuda de Bernardo Calderón, México.

Rodríguez de León, JuAn 1639. Panegýrico augusto castellano, Bernardo Calderón, México.

Ruiz Guerra y Morales, Cristóbal 1724. Letras felizmente laureadas y laurel festivo de letras, José Bernardo de Hogal, México.

Salazar y Torres, Agustín de 1694. Cýthara de Apolo. Ed. Juan de Vera Tassis, Antonio Gonçález de Reyes, Madrid.

\section{Referencias bibliográficas}

Bègue, Alain 2009. "La poesía de entre siglos a la luz de las aprobaciones (siglos XVII-XVIII)", en Paratextos en la literatura española (siglos XVI-XVIII). Eds. María Soledad Arredondo, Pierre Civil y Michel Moner, Casa de Velázquez, Madrid, pp. 91-107.

Bouza Álvarez, Fernando J. 2012. "Dásele licencia y privilegio": Don Quijote y la aprobación de libros en el Siglo de Oro, Akal, Madrid.

Cancino Cabello, Nataly 2017. "Los paratextos de artes y gramáticas misioneras americanas”, Nueva Revista de Filología Hispánica, 65, 2, pp. 407-440; doi: 10.24201/nrfh.v65i2.3101. 
Darnton, Robert 2014. Censors at work, W.W. Norton, New York.

Eagleton, Terry 1999. La función de la crítica. Trad. Fernando Inglés Bonilla, Paidós, Barcelona.

Fuhrmann, Manfred 2011. La teoría poética de la Antigüedad. Trad. Alfonso Silván Rodríguez, Clásicos Dykinson, Madrid.

García Aguilar, Ignacio 2009. Poesía y edición en el Siglo de Oro, Calambur, Madrid.

Garone, Marina 2014. Historia de la tipografía colonial para lenguas indígenas, CIESAS-Universidad Veracruzana, México.

Gracián, Baltasar 1967 [1648]. Agudeza y arte de ingenio, en Obras completas de Baltasar Gracián. Ed. Arturo del Hoyo, Aguilar, Madrid.

Gracián, Lorenzo 1725. Agudeza y arte de ingenio en que se explican todos los modos y diferencias de concetos, con exemplares escogidos de todo lo más bien dicho, assí sacro como humano, Juan Bautista Verdussen, Amberes.

Guibovich, Pedro 2014. "Autores, censores y producción de libros", en El libro en circulación en la América colonial. Producción, circuitos de distribución y conformación de bibliotecas en los siglos XVI al XVIII. Coords. Idalia García Aguilar y Pedro Rueda Ramírez, Quivira, México, pp. 95-111.

Horacio 1926. Satires, epistoles and ars poetica. Trad. H. Rushton Fairclough, Loeb Classical Library-Harvard University Press, Cambridge-London.

INFANTES, VíCTOR 2000. "La crítica por decreto y el crítico censor: la literatura en la burocracia áurea”, Bulletin Hispanique, 102, pp. 371-380; doi: 10.3406/hispa.2000.5048.

LAfaye, JacQues 2002. Albores de la imprenta. El libro en España y Portugal y sus posesiones de ultramar (siglos XV y XVI), Fondo de Cultura Económica, México.

Ontañón de Lope, Paciencia 1991. Reseña de "Alberto Porqueras Mayo, La teoría poética en el Manierismo y Barroco españoles", Nueva Revista de Filología Hispánica, 39, pp. 1142-1144; doi: 10.24201/nrfh.v39i2.850.

Pérez GonzÁlez, Andrea M. 2018. "La censura previa y la formación del juicio crítico lector: la evolución de un paratexto", Bibliográphica, 1, 2, pp. 52-76; doi: 10.22201/iib.bibliographica.2018.2.27.

RAma, Ángel 1998. La ciudad letrada, Arca, Montevideo.

Ramos Soriano, José Abel 2011. Los delincuentes de papel. Inquisición y libros en la Nueva España (1571-1820), Fondo de Cultura Económica, México.

Reyes Gómez, Fermín de los 2000. El libro en España y América: legislación y censura. (Siglos XV-XVIII), Arco/Libros, Madrid, 2 ts.

Ruiz Pérez, Pedro 2000. “Aristarcos y zoilos: límites y márgenes del impreso poético en el siglo xvi”, Bulletin Hispanique, 102, pp. 339-369; doi: 10.3406/hispa.2000.5047.

SÉneca 2010. Epístolas morales a Lucilio. Trad. Ismael Roca Meliá, Gredos, Madrid, 2 ts.

Simón Díaz, José 2000. El libro español antiguo, análisis de su estructura, Ollero \& Ramos, Madrid.

Snyder, Jon R. 2014. La estética del Barroco. Trad. Juan Antonio Méndez, Antonio Machado Libros, Madrid. (La balsa de la Medusa, 195).

Viñas Piquer, David 2002. Historia de la crítica literaria, Ariel, Barcelona. 
